\title{
On The Investigation Of Speech Acts
}

\author{
Gunay Qara Qarayeva \\ Azerbaijan University of Languages
}

\begin{abstract}
The speech act is considered to be one of the important and complex sources of communication. The importance of speech act has already been accepted and has attracted the attention of linguists as an investigation object. The speech act can be considered multicomponental. The article deals with the investigation of speech acts. It also investigates the performatives in speech acts. The speech act is considered to be an important and comlex communication source. The identity of performative sentences in speech acts is discussed in the article. The article writes that the performative sentences express declaration, announcement, description, confirmation, prediction, etc. Performatives are accompanied by the performance of speech act. The article states that L.Wittgenstein introduces speech acts as "language games" and it is widely discussed in the article. The opinions of Wittgenstein L. and Austin J.about speech acts are discussed in the article as well.
\end{abstract}

Key words: speech act, performative, verb, meaning, language, learning

\section{INTRODUCTION}

L.Wittgenstein describes the speech act as "language games". The speaker uses "the language games" introduced by L.Wittgenstein in the communication process. These language games are introduced as the vast array of rule-governed routines and communicative practices that speaker imploy (Wittgenstein 1953/2001, p.77).

It is necessary to stress that C.Augustine's child learner engages in the language games of clearly demonstrative learning. Yet word meanings are imparted to the child not by pointing to their referents, but the roles that words play in the game of ostensive learning (Thomas 2011, p.117). L.Wittgenstein's language games include 'giving oreders, and obeying them describing the appearance of an object . . . reporting an event - speculating about the event ... guessing riddles ...requesting, thanking, cursing, greeting, praying' (Wiitenstein 1953/2001, p.23). According to L.Wittengstein words appear deceptively parallel, but their roles in specific language games vary widely, the way knobs on the dashboard of a locomotive may look alike despite the fact that the engineer twists one, switches another, pulls another, moves still another to and fro (Wiitenstein 1953/2001, p.12). L.Wittgenstein aimed to clarify philosophy by bringing attention to its constituent language games, and the multifarious roles of words used in them (Thomas 2011, p.177).

It is necessary to stress that L.Wittgenstein added some "remarks" to J.Austin's conception about language learning. The first remark is called "ostensive teaching" (Wittgemstein $1953 / 2001$, p.6). This remark cannot include for the acquisition of functional categories such as articles or complementizers. It is noteworthy to mention that the meanings of these functional categories cannot be pointed out or even lexical categories such as adjectives, prepositions aside from nouns. Augustine did not supply the basis for the acquisition of grammar either. He (Augustine) only provided the isolated nouns. In addition, L.Wittgenstein considered Augustine's narrative inadequate to explain the multiple complex communicative 
and expressive activities that humans carry out through language, other than the rudimentary task of naming objects (Thomas 2011, p.176).

\section{DISCUSSION}

L.Wittgenstein did not accept Augustine's conventional assumptions about language. L.Wittgenstein's "language games" acts used to introduce "command" and to follow them. Besides, they are used to describe the landscape of the surroundings ... they give information about the event, they create conditions for different sides of events. They are also used to describe thankness, cursing, greeting, praising, etc. (Wittgenstein 1953/2001, p.23).

J.Austin commented on L.Wittgenstein's speech acts and writes: "The complexity of words are defined in the communication process". Their meanings are called "family resemblance" by J.Austin (Austin 1962, p.66-77). L.Wittgenstein claims that there exist words which can be explained by their definitions and meanings. He distinguised some words using the meanings of the word "game" such as tic-tac-toe; board games; Olimpic games; poker. The meanings of the word "game" do not express any single inductive definition. Yet it consititutes a recognizable class by forming 'a complicated network of similarities overlapping and crisscrossing: sometimes overall similarities, sometimes similarities of detail (Wittgenstein $1953 / 2001$, p.66). It is noteworthy to mention that according to modern psycholinguists the concept of "family resemblance" are meant to be valuable in modelling the structure of semantic relationships in the human mental lexicon.

In modern times, in the conveying of information, the speech act puts important influence to the communication process. The name of J.Searle is also mentioned while speaking speech acts. The theory of speech act by J.Searle was formed in 1969. At that time the study of the language was investigated in another direction. The investigation of the evolution of language was interested in by linguists at those times. The theories of Ch.Darvin such as "The Origins of the Species" (1859) ("Cinslərin mənşələləri”) and "The Descent of Man" (1871), ("Insanın yaranması"), the relative theory of A. Einstein (1871) and others may be given as examples.

J.Searle insisted that the main attention must be paid to the defining of the philosophy of language. So, J.Searle puts language theory agains to the linguistic philosophy (Searle 1969, p.3-4). The linguistic theory studies the relationship between mind and body, science and ethics, the nature of reality (onthology) and the epistemology of our surroundings. The language philosophy investigates the things studied by the linguistic philosophy. It means that to study the philosophy of language means to study the language itself. Citing to J.Searle, language studies language (Searle 1969, p.18). The aim of J.Searle was to study the language while investigating the theory of speech acts. He also tried to study the development of the language in the national and ethnic borders. J.Searle stated the movement of the language through his speech act theory.

J.Austin's name is also mentioned in the investigation of speech acts. Austin especially studies the nature of performatives and constatives.

\section{ANALYZES}

J.Austin distinguishes the following speech acts (Austin 1962, p.151):

\section{Verdictives.}

The following can be given examples to the verdictives such as acquit (bəraət qazandırmaq), convict (məhkum olmaq, etmək), assess (cərimə təyin etmək), diagnose (diaqnoz qoymaq), 
calculate (hesablamaq), analyse (təhlil etmək), describe (təsvir etmək), estimate (qiymətləndirmək), measure (ölçmək), etc.

It is necessary to stress that verdictives have obvious connexions with truth and falsity, soundness and unsoundness and fairness and unfairness.

\section{Exercitives.}

Appoint (səs vermək), dismiss (çağırmaq), degrade (səsləndirmək), demote (tövsiyə etmək), excommunicate (istefa etmək), name (düzəltmək), order (әmr etmək), command (әmr etmək), sentence (ölüm hökmünə məhkum etmək), bequeath (vəsiyyət etmək), entreat (dua etmək), pray (yalvarmaq), dedicate (həsr etmək), repeal (ləğv etmək), recommend (tövsiyə etmək), resign (istefa etmək), direct (istiqamətləndirmək), advise (məsləhət görmək), proclaim (elan etmək), urge (qızışdırmaq), warn (xəbərdarlıq etmək), vote (for) (səs vermək), etc., can be given examples to exercitives.

\section{Commissives.}

J.Austin writes: "Commissives are used to describe to commit the speaker to a certain course of action". The following are the examples of commissives:

Promise (vəd vermək), undertake (qarşısına məqsəd qoymaq), covenant (əhd etmək), contract (müqavilə bağlamaq), give my word (vəd vermək), declare my intension (məqsədini elan etmək), mean (to) (ifadə etmək), agree (razllaşmaq), oppose (qarşı çıxmaq), favour (lehinə çıxmaq), swear (and içmək), purpose (məqsəd qoymaq), vow (əhd bağlamaq), adopt (qəbul etmək), declare (for) (elan etmək), pledge (əhd etmək), guarantee (zəmanət/təminat vermək), bet (mərc gəlmək), consent (razılaşmaq), contemplete (müşahidə etmək), etc.

\section{Behabitives.}

The notion of reaction to other people's behaviour and fortunes and of attitudes and expressions of attitudes to someone else's past conduct or imment conduct are considered to be behabitives. They are used to express or describe what our feelings are. The following can be given as examples:

While apologizing we have to say apologize (üzr istəmək); while thanking we have to say thank (təşəkkür edirəm); for expressing our sympathy we have to say deplore (xoşlamamaq), commiserate (rəğbət bəsləmək), compliment (tərifləmək), condole (başsağlığı vermək), congratulate (təbrik etmək), felicitate (təbrik etmək), sympathize (rəğbət bəsləmək); for attitudes we have to say resent (küsmək; təəssüf etmək), do not mind (etiraz etmək), pay tribute (xərac ödəmək), criticize (tənqid etmək), grumble about (donquldanmaq), complain of (şikayət etmək), applaud (alqışlamaq), overlook (gözdən keçirmək), commend (tərifləmək), deprecate (gizlətmək); for greetings we have to say welcome (salamlamaq), bid your farewell (sağollaşmaq); for wishes we have to say bless (xeyir-dua vermək), curse (lənətləmək), toast (tost demək), drink to (şərəfinə içmək), wish (arzulamaq); for challenges we have to say dare (cəsarətləndirmək), defy (təhqir etmək), protest (etiraz etmək, qarşı çıxmaq), challenge (duelə çağırmaq, yarışa çağırmaq), etc.

\section{Expositives.}

Expositives are considered to introduce the acts of exposition involving the expounding of views, the conducting of arguments, and the clarifying of usages and of references. The following can be given examples to expositives:

Affirm (təsdiq etmək), state (bəyan etmək), describe (təsvir etmək), identify (müəyyən etmək), testify (şəhadət vermək), report (məlumat vermək), concede (imtina etmək), withdraw (uzaqlaşmaq, çəkinmək), object (to) (etiraz etmək), apprise (xəyanət etmək), rejoin (qoşulmaq), revise (yoxlamaq), distinguish (fərqləndirmək), formulate (yaratmaq), deduce 
(nəticəyə gəlmək), recognize (tanımaq), postulate (bəyan etmək), illustrate (təsvir etmək), neglect (biganə qalmaq), believe (inanmaq), conjecture (güman etmək), demur (to) (etiraz etmok), etc.

J.Austin considers the exercitives as an assertion of influence or exercising of power. The first act introduces a verdict. This type of verdict is used by a jury, arbitrator, or umpire. The exercitives are used to introduce of powers, rights, or influence. The third type is used to describe promising, or undertaking, etc. They also include declarations or announcements of intention. They are not promises, and also rather vague that may be called espousals such as siding with. J.Austin states that commissives have obvious connections with verdictives and exercitives.

Behabitives are considered to be a very miscellaneous group. They introduce social behaviour. Apologizing, congratulating, commending, condoling, cursing, and challenging can be given as examples (Austin 1962, p.152).

According to J.Austin, expositives are difficult to define. They describe something which make plain our utterance fit into the course of an argument or conversation. They also introduce the ways of utterancing words or something expository. /I reply// (Mən cavab verirəm), /I argue// (Mən razılaşıram), /I concede// (Mən imtina edirəm), /I illustrate// (Mən təsvir edirəm), /I assume// (Mən güman edirəm), /I postulate// (Mən bəyan edirəm), etc. (Austin 1962, p.152).

J.Austin considers the last two classes most troublesome. The linguist writes that these classes are not clear or cross-classified. He considers behabitives troublesome as they seem too miscellaneous altogether. Though expositives are considered to be enormously numerous and important. They both seem to be included in the other classes and at the same time to be unique in a way that are unclear in some way.

R.Carter and M.McCarter distinguishes the following speech acts (Carter and McCarthy 2006, p.680):

Constatives. The speaker asserts something about the truth of a proposition. It is used to introduce affirming, claiming, concluding, denying, exclaiming, maintaining, predicting, stating beliefs, etc.

Example 1: /I confess to stealing the money// (Pulu oğurladığımı etiraf edirəm (boynuma alıram)).

Directives. The speaker intends to make the hearer act in a special way. It is used to introduce advising, asking, challenging, commanding, daring, forbidding, insisting, persisting, permitting, questioning, prohibiting, requesting, suggesting, warning.

Example 2: /If your boss gives you some instructions, it is best to get it out of the way quickly to show him you can handle any job// (Әgər müdirin sənə tapşırıq verirsə, onun tapşırdığını cəld yerinə yetir ki, sənin hər bir işin öhdəsindən gəlidiyi bilsin).

Commissives. While performing this act the speaker commits to a course of the action. It is used to introduce guaranteeing, offering, inviting, promising, vowing, undertaking.

Example 3: /You may stay us some more days// (Siz bir neçə gün də bizimlə qala bilərsiniz). 
Expressives (or acknowledgements). Performing this act the speaker expresses an attitude or reaction concerning a state of affairs. It is associated with acts such as apologizing, appreciating, complimenting, condemning, congratulating, regretting, thanking, and welcoming.

Example 4: /I am so sorry for having kept you waiting// (Sizi gözlətdiyim üçün çox təəssüf edirəm).

Declarations. The speaker performs the speech act solely by making the utterance. The speaker expresses judgments, etc.

Example 5: [The marrage officer says to the newly weddings]:

/I pronounce you man and wife// (Sizi əv və arvad elan edirəm).

Example 6: [The leader of the meeting says]:

/I declare this meeting closed// (Bu iclası bağlı elan edirəm).

Each speech act has its utterance in this division. For example, directives are used to introduce for judging, constatives are used to introduce claiming, denying, etc. Each of these types is realized in the speech act not depending on their functions.

The speech acts in the sent information are uttered differently. According to J.Austin, the first four acts can be distinguished easily, though the fifth one (expositives) have some complex features (Austin 1962, p.152). Expositives clarify the purpose of the speaker's utterance. They make people use the wordw that should be chosen for their purpose (Austin 1962, p.152).

Any performance that is used in the speech act can perform different combinations with different styles and structures. At this point, any completeness is not needed. J.Austin writes: "I cannot suggest complete succession and the sorting according to the easiness of the speech acts. Sometimes the choice of the speech act may confuse me too (Austin 19623, p.152). The aspect that I suggest can be used in all classes of speech acts" (Austin 1962, p.152).Depending on the speakers' background knowledge, and the volume of the knowledge, the experience of the participants, their ability of using different language means, their psychological situation and other factors, speech acts may be performed differently way by the speakers. Speech acts may include the following features:

1) the purpose of the communication; 2) the information may be created; it may be new, or given; 3) the verbal and non-verbal usage of speech acts; 4) the ability of persistence and effectiveness; 5) the realization of each communication through purpose.

The intent of the speaker stands on the first line among these features. Communication cannot exist without intent. People can perform various sounds withoud any purpose such as "Oh!", “Ow!”, “E.. damn it!”, etc. These acts cannot be planned. They are considered to be emotive "uses" of language. As they lack intent they are not meant to be acts. Screams are not purposefully issued, so they may be emitted. Therefore, they are not believed to be acts, but as events. Unlike them, speech acts require intent or purpose. For instance, When Ali says to Ahmad /It is snowing now// (İndi qar yağır), Ali utters the speech act with the purpose of letting Ahmad be aware of the weather conditions outside. His purpose may not be necessarily formed as the result of prior deliberation. It is the act that is performed non-consciously, and it seems to be simply built into the action of uttering /It is snowing now//. So, Ali's intention is to send a message to Ahmad about the snow. It is necessary to underline that in the communication process Ali has also another intension. This intension is also a non-conscious one. This intention is the one that to get Ahmad to recognize that the message sent to him is 
sent intentionally. The second intention is to get Ahmad to recognize the first intention. Obviously, the second intention is to help make it clear to Ahmad that Ali is responsible for the speech act uttered. In this case, a question arises about the truth, correctness, appropriateness, etc. of the speech act, the hearer can point to the speaker as the one responsible for its issuance.

All sentences in the language depending on the meaning of the sent information may be true, or wrong. Let us analyse the notions of true or wrong meanings of the sentences. For example, /This bull is dangerous// (Bu öküz təhlükəlidir). The sentence is correct according to its semantic and grammatic meanings. Now the other example: /This bull may be dangerous// (Bu öküz təhlükəli ola bilər). The usage of the modal word "may be" proves that there is some hesitation in the meaning of the sentence. Because of this, the sentence cannot be considered to be a correct one completely. It is necessary to stress that whether the sentence is true or wrong according to its meaning is its traditional feature (Austin 1962, p.56).

Now, let us look through the meanings of the following sentences:

\section{Example 1:}

The marriage officer asks:

- ¿Do you take this woman to be your lawful wedded wife? (Bu qadını qanuni zövcən olaraq qəbul edirsənmi?)

-/I do// (Edirəm).

\section{Example 2:}

/I name this ship the Queen Elizabeth// (Mən bu gəmini Kraliça Elizaveta adlandırıram).

\section{Example 3:}

/I give and bequeath my watch to my brother// (Mən saatımı qardaşıma verirəm və ona vəsiyyət edirəm).

/I bet you sixpence it will it will rain tomorrow// (Mən sizinlə 6 pensdən mərc gəlirəm ki, sabah yağış yağacaq).

J.Austin writes: "In these examples it seems clear that to pronounce the sentence is not to describe my doing of what I should be said in so uttering to be doing or to state that I am doing it: it is to do it. None of the sentences cited is true or false". It is necessary to underline that it needs argument no more than that 'amin' is not true or false. J.Austin suggests to call such kinds of sentences performative sentences, or performative utterances, or shortly performatives. The word is derived from 'perform' meaning 'action'. It denotes that the issuing of the utterance is the performing of an action. It is not normally thought of as just saying something.

Cited by J.Austin it can be said that there are some kinds of terms which may cover some wider or narrower class of performatives. Many performatives can be called contractual (/I bet// 'Mən mərc gəlirəm') or declaratory (/I declare war// 'Mən müharibə elan edirəm') sentences (Austin 1962, p.7).

There are some kinds of performatives whose meanings do not require any explanation. According to their meanings performatives are divided into "happy" performatives and "unhappy" performatives. Let us make such a context: During the wedding the marriage officer asks: ¿Do you take this woman to be your lawful wife? (Bu qadını qanuni zövcən olaraq qəbul edirsənmi?) They answer: /I do// (Edirəm). This wedding ceremony may be observed in any nation's wedding traditions. By saying /I do// the participants do not send any information. He 
(she) only performs his (her) marriage act. They share their happiness. They perform this act by saying certain words. This kind of act do not require any proof.

The other example: Let us imagine the people who are observing the horse races. Each one wants his/her own horse to win, and they pray for this. Each of them says: /I bet my horse will win// (Mərc gəlirəm ki, mənim atım qalib gələcək). In such situations every person uses happy or unhappy performatives for sending his/her emotional inward feelings to the outside world. The act of marrying, betting, bequeathing, christening, etc. are considered to be happy performatives. The unhappy feelings of people such as failure of something, saddnes, etc. can be called unhappy performatives.

J.Austin gives some division of happy and unhappy performatives (Austin 1962, p.26):

1) Performative utterance. /I apologize// (Üzr istəyirəm). This utterance may be called a happy performative in a certain situation. The sentence may be used in the present continuous tense form too such as /I am apologizing//.

2) The particular persons and circumstances in a given case must be appropriate for the invocation of the particular procedure invoked.

3) The procedure must be executed by all participants correctly.

4) The procedure must be executed by all participants completely (Austin 1962, p.27).

If any of these relationships in the speech acts are destroyed, then we may have unhappy performatives. For instance, /I devorce you// (Səni boşayıram). This utterance is considered to be unhappy performative.

J.Austin states that there are two kinds of performatives as well. They are explicit performatives and implicit performatives. Explicit performatives mean something whose meanings are clear. Implicit performatives mean something whose meanings are not clear. For example, "Go!" (Get!) the word expresses imperative form. According to J.Austin, these kinds of sentences can neither be true nor wrong. These kinds of sentences cannot be considered to be explicit performatives. While hearing this sentence it is not clear whether the speaker means a command or some other kinds of performance. Distinguishing the differences between explicit and implicit performatives it is necessary to study their usage of situations. For example, father says to his son: "Go away! I do not want to see you here! (Get! Gözüm görməsin səni!) This sentence expresses explicit performative.

Other examples of explicit performatives:

/I now pronounce you man and wife// (Sizi ər arvad elan edirəm).

¡I order you to go! (Bu əmrdir. Get!)

/I christen you// (Sizi xaç suyuna salıram).

/I accept your apology// (Üzürünüzü qəbul edirəm).

/I sentence you to death// (Sizi ölüm hökmünə məhkum edirəm).

/I divorce you, I divorce you, I divorce you// (Səni boşayıram).

/I swear to do that, I promise to be there// (Orada olmağa and içirəm).

/I apologize// (Üzr istəyirəm).

/I dedicate this...// (...book to my wife; ...next song to the striking Stella Doro workers, etc.) (həsr edirəm...).

/The court is now in session// (Məhkəmə indi sessiyadadır).

/War is declared// (Müharibə elan olunur).

/I resign// (İstehfa edirəm.

/You're [hereby] fired// (İșdən qovulursan). 
It is noteworthy to distinguish the performative verbs used in speech acts. Some of them are the following: promise (söz vermak), invite (davat etmak), apologize (üzr istamak), predict (glacakdan xabar vermak), vow (and içmak), request (xahiş etmak), warn (xabardarlıq etmak), insist (təkid etmak) və forbid (qadağan etmək), etc.

J.Lyons writes: "Explicit performatives are the performatives whose usage makes it clear which act is performed in the speech (Lyons 1995, p.175). J.Thomas claims that the usages of explicit performatives can be realized through performative verbs. The speaker (or the performer) uses such a mechanism to eliminate the misunderstanding that may arise through his/her speech (Thomas 1995, p.47). Examples:

/I command you to stay// (Qalmağını əmr edirəm).

¿Will you stay please? (Zəhmət olmasa qalarsanmı?)

In the first exampe the speaker introduces imperative proposition. The speaker's intent is to make the listener stay. In the example the performative verb is used, and the meaning of the sentence is clear.

In the second example the meaning is a little ambiguative. This sentence can be understood in two ways. This sentence can be literally accepted, yet it can be executed as a blessing question or as a comrade, and even as an order to stay. At this point, the listener may be confused and may not catch the speaker's intention successfully. Thus, these sentences can be called implicit performatives.

G.Yule claims that explicit and implicit performatives cannot be considered to be equivalents (Yule 1996, p.97).

\section{CONCLUSION}

It is necessary to stress that the investigation of performatives in the speech is considered to be very important nowadays. Though it is a new source of investigation many are interseted in it. The different kinds of speech acts such as performatives, constatives, etc. have a lot of differences and similarities, and all need to be investigated comprehensively. In the present article we only touched upon some of the facts dealing with them. A lot will be investigated in our future essays.

\section{References}

Austin J.L. How to do things with words. Oxford: Oxford University Press, 1962.

Abdullayev A.A. Actual linking and text. Baku: Khazar University Press, 1998.

Lyons J. Linguistic Semantics: An Introduction. Cambridge: Cambridge University Press, 1995.

Ronald C. and M.McCarthy. Cambridge Grammar of English. Cambridge: Cambridge University Press, 2006.

Searle J. Speech acts. Cambridge: Cambridge University Press, 1969.

Thomas J.Meaning in Interaction: An Introduction to Pragmatics. London: Longman, 1995.

Yule G. Pragmatics. New York: Oxford University Press, 1996.

Veysalli F.Y. The basis of Linguistics. I Part - Introduction; II Part - The inner structure of Language. Baku: Mutarjim, 2013.

Wittgenstein L. Philolosophcal Investigations: the German Text, with a Revised English Translation, 2001 (3rd edn, G.E.M. Anscombe, trans.), B; ackwell, Oxford (original text published 1953). 